claims to such knowledge from those that are not". This (as the Council of the Royal Society would correctly perceive) is the faith upon which science is built, and the disciplinary code, at platoon, regimental, and divisional level, which binds it together in its war on ignorance and error. And yet

there are perhaps occasions when such simple loyalties fail us, and the direction of the Army itself has to be called into question.

John Ziman is Professor of Physics at the University of Bristol, $U K$.

\section{Updated science policy \\ almanac}

\section{Austen Albu}

Science and Government Report International Almanac, 1978-1979. Edited by D.S. Greenberg and A.D. Norman. Pp. 368. (Science and Government Report, Inc., P.O. Box 6226, 3736 Kanawha St NW, Washington DC, 20015, 1979.) \$54.

IT can be assumed that any study published today on government policy and organisation for science will be more concerned with technology than with pure science. Whether in captialist or communist countries this represents a victory for those pre-War marxist scient ists who advocated planned support for science applied to utilitarian ends. The new edition of this valuable report, covering a period when economic difficulties restrained the expediture of most countries on R\&D, makes it clear that pure science plays a decreasing role in government support policies compared with applied science and technology. Even Israel, which claims high support for basic research, based on its traditional approach to learning, has seen a significant increase in the proportion of applied research and development in the past few years. Although they do not all follow the same pattern, these national reports give an invaluable picture of recent developments in public policy and attitudes, and in changes in organisation for scientific advice and the carrying out of policy.

All governments support $R \& D$, but the degree to which they do so financially and the organisations they use for the purpose vary a good deal. Britain and France seem to be among those countries with the most centralised structures among the advanced industrial nations. Even the USSR, if one forgets the overarching position of the Party, seems to have a wider range of institutions, although they are constantly changing. The growing emphasis on R\&D to improve industrial production seems to have led to some decline in the prestige of the Academy of Sciences in face of the State Committee for Science and Technology.
In the United States the growth of anxiety in official circles about the country's apparent diminishing capacity for industrial innovation was one reason for President Carter's proposals to raise the rate of growth of funds for $R \& D$, especially basic research. Congress, however, had rather different ideas and kept the 1979 expenditure to a total only fractionally more than that of 1978 . One of the results of the increased involvement of governments in science and technology is the politicising of the decision-making process. In that most democratic of federations, Switzerland, the voters in referenda have displayed hostility to expansion of the universities and to subsidies to industry for R\&D. This may be of little importance as Switzerland has the highest per capita rate of $R \& D$ expenditure in the world; $80 \%$ of it by private industry. Apart from wishing to curtail government expenditure, some voters in most countries are becoming increasingly interested in 'ethical' aspects of science or questions of the effects of technology on 'life style'. The main targets at present are nuclear energy and recombinant DNA. The former is an obvious embarassment for governments struggling with energy problems and no doubt adds to the growing part energy plays in national research programmes. Popular interest in the supposed dangers of recombinant DNA has been greatest in the USA and UK; in most other countries it has only attracted the attention of scientists and administrators.

The richer countries are concerned with problems of health research, both its changing nature and its accelerating cost. In the USA the Secretary of the Department of Health, Education and Welfare addressed scientists last year on the need to devise "health research principles" to be used for planning a "rolling" five year budget for the Department's programmes. The Federal Republic of Germany has published a programme of Promoting Research in the Service of Health, 1978-1981, of which an extremely interesting excerpt from the English translation is reproduced. It includes an examination of the difficulties of health research and a detailed list of fields in which greater R\&D efforts would seem to be necessary.

So far the Trades Union in most countries have not shown much sustained interest in the problems involved in the results of scientific research. Only in the Scandinavian countries have permanent bodies been established by the Unions to keep them under survey. In France the scientific associations acted as pressure groups during the Presidential election of 1979 in which science policy played a prominent part.

Some rather unexpected figures in the output of scientist are revealed. In Sweden there was a fall in the output of Doctorates in the Natural Sciences between 1970 and 1976 from 461 to 172 . In Britain, during the period of university growth in the $1960 \mathrm{~s}$ scientific subjects got left behind, so that the "swing away from science" in the 1970 's seems by contrast fairly modest On the other hand engineering, at least in numbers, kept pace with university expansion. This, however, does not take account of a rapidly growing number of foreign students. The most unbalanced figures come from India which, in 1977, produced 140,600 graduates in the Natural Sciences and 15,000 in Engineering; bringing the total number of science graduates in the population to $1,182,272$ of whom $16.1 \%$ were unemployed and of engineers to 251,860 of whom $2.4 \%$ were unemployed.

The most significant differences between nations lie in the ratio of government to private industry financed $R \& D$ and the proportion of military expediture. This may provide at least a partial explanation for the decline of British industrial performance. In Britain, France and the USA goverment provides more than half the nation's R\&D funds; in Germany, Italy, the Netherlands, Sweden and Canada between $\mathbf{4 0}$ and $50 \%$. In Japan the figure is about $30 \%$, but Japan has the third largest R\&D programme in the world. What is more significant is the fact that in the UK annd the USA roughly $50 \%$ of government R\&D funds are spent on military programmes against a EEC average of $23 \%$, a German figure of 12 and Japanese of 2. In all the major Western countries except the UK the share of government R\&D spent on military programmes declined during the 1970 s. In the UK it increased between 1970 and 1976 from 41 to $48 \%$. If research expenditure is to be reduced these figures indicate where the possiblities of cuts should at least be scrutinised. On the other hand it seems that R\&D activity by industry has been declining in the UK while that of the UK's main competitors has been rising; a matter which must be of concern to a government committed to reversing the decline of British industrial competitiveness.

This is the second year of publication of this important almanac. As an essential source of reference for scientific administrators, politicians and students of the subject it is to be hoped that it has now become firmly established in the rather overgrown forest of journals dealing with science policy.

Austen Albu is a Visiting Research Fellow of the Science Policy Research Unit, University of Sussex, Brighton, UK. 